\title{
The Scope of Corporate Profit Tax Consolidation: the Effect of Changing the CGT Entry Threshold
}

\author{
Alena V. Khaperskaya \\ Department of Management \\ National Research Tomsk Polytechnic University \\ Tomsk, Russia
}

Natalia V. Pokrovskaia

Department of Credit Theory and Financial Management

Saint-Petersburg State University

Saint Petersburg, Russia

\author{
Viktor V. Ivanov \\ Department of Credit Theory and Financial Management \\ Saint-Petersburg State University \\ Saint Petersburg, Russia \\ Kristina A. Bannova \\ Department of Management \\ National Research Tomsk Polytechnic University \\ Tomsk, Russia \\ bannovaka@yandex.ru
}

\begin{abstract}
In the Russian Federation, corporate profit tax consolidation implicates rather tight restrictions on organizing a CGT. Even though earlier it was announced that the restrictions would be loosened, a moratorium has been declared on organizing consolidated groups of taxpayers since 2015. The purpose of our study is to outline existing criteria for creation CGTs and their influence on the scale of corporate profit tax consolidation in Russia as well as giving an outlook on CGTs expansion by assets and revenue. The results of organizing the CGT institution in 2012-2015 revealed their crucial significance for the Russian economy in terms of paid corporate profit tax. A model was based on the data collected from 10,000 major Russian companies describing the change of CGT share in CPT proceeds in case of lowering the CGT entry threshold. It was concluded that the relation between the CPT share and assets value or revenue differs only in case of major companies. It is expedient to specify only one criterion-either assets value or revenue-for lowering the threshold. Either choice requires a separate argumentation.
\end{abstract}

Keywords-consolidated group of taxpayers, corporate profit tax, assets, revenue

\section{INTRODUCTION}

The possibility to pay the corporate profit tax (CPT) within a consolidated group of taxpayers (CGT) has been a part of the Russian tax legislation since 2012.

The introduction of CGTs had been discussed since the early 2000s [1]. The legislative permission to form CGTs was given simultaneously with making significant amendments to the regulation of transfer pricing that was modified to conform to OECD Transfer Pricing Guidelines for Multinational Enterprises and Tax Administrations. At the same time, transfer pricing no longer regulated CGTs what significantly reduced corporate costs of a group [2].

The possibility of organizing a CGT was supposed to be available for major taxpayers. It was planned to lift tight restrictions on entering a CGT later on in order to extend the institution to a broader range of Russian companies. It should be noted that initially a whole number of new fiscal terms introduces in Russia in the 2000s was meant for major taxpayers, but after 2-3 years of successful implementation of the process it was extended to other companies.

However, CGTs functioned for 3 years and a moratorium for organizing new ones and extending existing ones has been declared since 2015 [3]. The moratorium was prolonged later on until 2018. Existing mechanism of tax consolidation has been supposed to be further developed including the part on requirements for organizing CGT.

The purpose of this paper is to describe the scale of organizing CGTs by Russian companies under current restrictions as well as giving an outlook on CGTs expansion by assets value and revenue.

\section{METHODOLOGY}

The first stage of the study analyses group taxation conditions in different countries in order to define tax consolidation regimes with criteria similar to the Russian ones. If such countries are identified, correspondent entry thresholds and consequences will be analyzed.

The next stage describes the scale of organizing CGTs in Russia. A share of CGTs in total CPT proceeds was used as a key factor of CGT's significance for the state.

The third stage introduces a model with a lowered CGT entry threshold by assets value and revenue in terms of CPT share paid by CGTs. On the SPARK data based, 10,000 companies were selected that paid the highest amount of CPT as of 2014. For the selected companies, share in CPT proceeds was calculated-a share from the total 2014 CPT proceeds according to the Federal Tax Service-and a bar chart representing companies distribution according to their share in total CPT proceeds was generated in order to describe the density of taxpayers. 
Then the relation between the assets value and CPT share paid by companies with assets exceeding a certain level was defined, that was followed by a corresponding model (linear$\log$ model). The same process was used for the model of relation between revenue and CPT share paid by companies with revenues exceeding a certain level. Calculation was made in the Stata11.

\section{CGT ENTRY TRESHOLD CRITERIA}

According to Worldwide Tax Summaries 2015\16, group taxation is permitted in more than 50 countries. In most cases it assume tax consolidation regime, but it is possible as well tax unity (Netherlands, Luxemburg) and group relief provisions (Cyprus) [4,5]

Requirements to companies entering a group most often concern their participation share (from $50 \%$ in Austria, Germany, Italy, Liechtenstein, Malta - to $100 \%$ in Australia, Japan) [6] In most countries, there is a specific provision whether group taxation should be applied exceptionally to domestic companies or to foreign companies as well. Some countries put forward requirements to the activity type of a company in a group, thus in Israel, a group for taxation purposes could include only industrial companies of the same line of business.

In some cases, the period of holding a stake in a company is stipulated (e.g. over a year in Finland and Portugal) or the stake's size (e.g. capital of ordinary shares exceeding MYR 2.5 million in Malaysia). Multicriterion provisions on group taxation in Poland stand out against this background. In this country in addition to share of the parent company at least $95 \%$ of the equity of each of the dependent companies, there are also other conditions (an average capital of all companies and profitability ratio of the group) which must be met to establish the 'tax capital group' [7]. However, the required conditions are extremely demanding and very few taxpayers of this type exist [4].

New Russian legislation gives a most detailed list of requirements to a group for organizing a CGT. These include business line, financial health, and continuous operation of group members. Numeric parameters for entering a CGT are also stated:

1) Direct or indirect participation by a company in the capital of other companies should be at least $90 \%$;

2) The total amount of taxes paid (VAT, excises, CPT, and mineral extraction tax) should comprise at least 10 billion roubles;

3) The total revenue of the group should comprise at least 100 billion roubles;

4) The total assets value of the group should comprise at least 300 billion roubles.

Therefore there are significant differences in requirements for consolidation in Russia in comparison with the legislation of most countries that assume group taxation. Other countries put forward requirements exclusively concerning participation share of every company within a group without other numeric limitations such as revenue, assets, taxes paid etc. For this reason, it was impossible to find a country to compare entry thresholds.

Main characteristics of Russian CGTs reflecting their significance are found in table 1.

Strict criteria for organizing a CGT in Russia predetermined the creation of less than 20 taxpayers groups. At the same time, CGTs pay a quarter of total CPT proceeds and have a crucial significance for the Russian economy [8].

High density of businesses in Russia should be noted. This is underpinned by the fact that on the 5th of February 2015 the government of the Russian Federation approved a list of systemic important companies. The list included 199 enterprises, in particular holdings and vertically integrated companies the revenue of which accounted for over $70 \%$ of aggregate national income, the number of their employees exceeding $20 \%$ of total number of those engaged in the economic process. Companies that organized a CGT also were on the list accompanying the town-forming enterprises in numerous Russian company towns [19].

TABLE I. THE SCALE OF CORPORATE PROFIT TAX CONSOLIDATION BY CGT IN 2012-2015

\begin{tabular}{|c|c|c|c|c|}
\hline Indicator & $\mathbf{2 0 1 2}$ & $\mathbf{2 0 1 3}$ & $\mathbf{2 0 1 4}$ & $\mathbf{2 0 1 5}$ \\
\hline Number of CGTs, pcs. & 11 & 15 & 16 & 16 \\
\hline $\begin{array}{c}\text { Number of companies within } \\
\text { CGTs, pcs. }\end{array}$ & 197 & 313 & 398 & nla \\
\hline $\begin{array}{c}\text { Number of companies and their } \\
\text { separate subdivisions in different } \\
\text { regions of Russia, pcs. }\end{array}$ & 1,559 & 2,251 & 2,406 & 2,242 \\
\hline $\begin{array}{c}\text { Percentage of companies within } \\
\text { CGT in relation to the total } \\
\text { number of companies }\end{array}$ & $0,15 \%$ & $0,21 \%$ & $0,22 \%$ & $0,24 \%$ \\
\hline $\begin{array}{c}\text { Share of CGTs in total CPT } \\
\text { proceeds }\end{array}$ & $23 \%$ & $23 \%$ & $24 \%$ & $25 \%$ \\
\hline
\end{tabular}

Data provided based on information from Russian Audit Chamber, Russian Federal Tax Service.

The criteria used for organizing CGTs had no justification. Logically, CGTs were meant for highly interrelated groups and were supposed to be formed from major taxpayers with high revenue and significant assets value.

\section{EFFECT OF CTG EXPANSION BY ASSETS VALUE AND REVENUE}

According to Federal Tax Service's Report \#5P in 2014, CPT was paid by 954,531 companies. On the SPARK data base, 10,000 companies were selected that paid the highest amount of CPT or $1.05 \%$ of the total number of corporate profit taxpayers who made a profit.

The selected 10,000 companies transferred $50.46 \%$ of profit tax proceeds. Distribution bar chart according to corporate profit tax share is displayed on Figure 1.

The figure represents extremely high density of CPT paid by largest companies. 10 largest taxpayers paid $7.52 \%$ of total CPT in 2014, 100 largest companies accounted for $21.33 \%$, and $36.81 \%$ accrued to the first 1000 . The nature of company distribution according to the selected criterion can be clearly described as exponential. 
The figures of 2014 sales revenue and assets value as of the end of 2014 were used in order to give an outlook on lowering CGT entry threshold. The models were created based on two criteria out of four and in terms of separate companies but not the groups they formed due to the fact that it was impossible to acquire information regarding the amount of taxes paid as well as difficult to define stakes held. It is assumed that the analysis of relation between CPT paid and assets value and revenues of separate companies reflect the relation in terms of company groups.

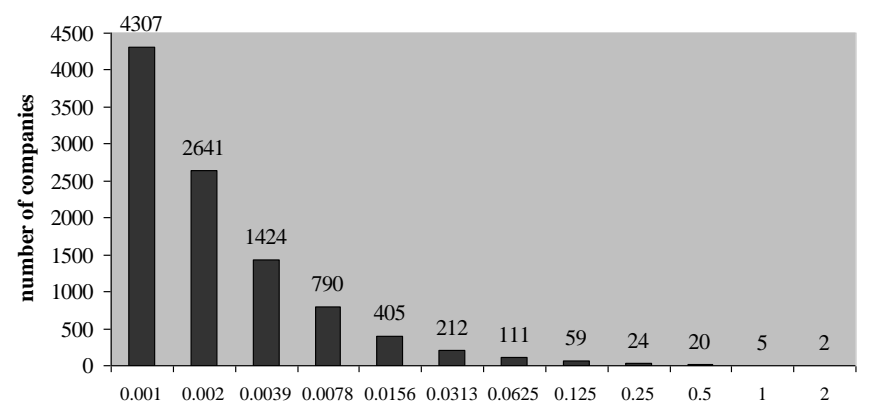

Share in CPT proceeds

Fig.1. Distribution of 10,000 largest taxpayers according to share in CPT proceeds in 2014

The selection included the largest taxpayers with information available on assets value and profit. Therefore the selection included 9,801 companies that paid $49.34 \%$ of total CPT proceeds in 2014.

The correspondence of the share in CPT proceeds to the assets logarithm is displayed on Figure 2.

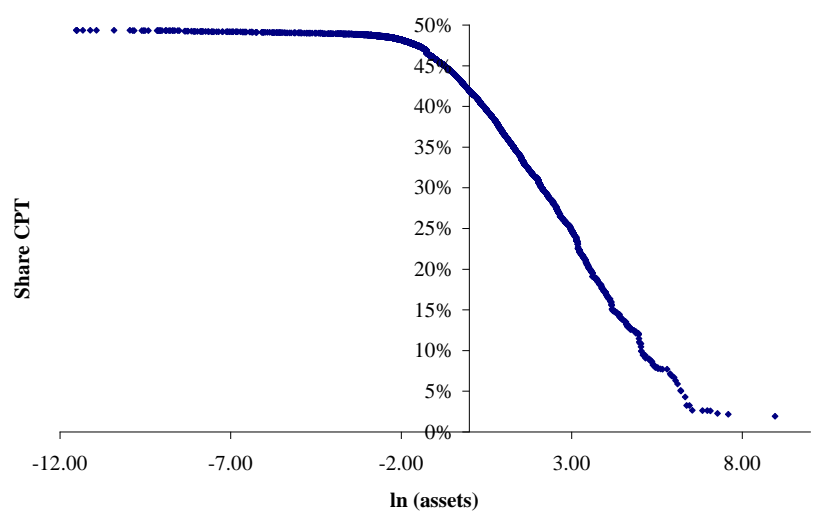

Fig. 2. Cumulative share in corporate profit tax proceeds depending on logarithm of assets

The relation between the selected parameters is unsteady. There are two areas that can be pointed out at the graph: one with assets logarithm being greater than or equal to (-1.8844) corresponds with assets of 0.15195 billion roubles - and one with logarithm being less than the specified value.

If $\ln$ Assets $\geq-1,8844$ (asssets $\geq 0,15195$ ):

ShareCPT $=41,1-5,14 *$ LnAssets

If $\ln$ Assets < -1,8844 (asssets < 0,15195):

ShareCPT $=48,06-0,16 *$ LnAssets where:

ShareCPT - cumulative share in corporate profit tax proceeds, [\%]

lnAssets - company assets logarithm.

Details of models are shown in tables 2-3.

TABLE II. MODEL OF CPT SHARE DEPENDING ON LOGARITHM OF ASSETS (IF ASSETS $\geq$ RUB $0.15195 \mathrm{BN}$ )

\begin{tabular}{|c|c|c|c|c|c|c|}
\hline Source & SS & $d f$ & MS & & \multirow{3}{*}{$\begin{array}{l}\text { Number of obs }= \\
\mathrm{F}(1, \quad 8635) \\
\text { Prob }>\mathrm{F} \\
\text { R-squared } \\
\text { Adj R-squared } \\
\text { Root MSE }\end{array}$} & \multirow{3}{*}{$\begin{array}{l}=8637 \\
=\quad \\
=0.0000 \\
=0.9762 \\
=0.9762 \\
=1.1022\end{array}$} \\
\hline $\begin{array}{r}\text { Mode1 } \\
\text { Residual }\end{array}$ & $\begin{array}{l}430241.194 \\
10490.4104\end{array}$ & $\begin{array}{rr}1 & 430 \\
8635 & 1.2\end{array}$ & $\begin{array}{l}0241.194 \\
21487092\end{array}$ & & & \\
\hline Total & 440731.605 & 8636 & .0342294 & & & \\
\hline ShareCPT1 & Coef. & Std. Err. & $\mathrm{t}$ & $P>|t|$ & [95\% Conf. & Interval] \\
\hline $\begin{array}{r}\text { LnAssets } 1 \\
\text { _cons }\end{array}$ & $\begin{array}{r}-5.141976 \\
41.10497\end{array}$ & $\begin{array}{l}.0086405 \\
.0119442\end{array}$ & $\begin{array}{l}-595.10 \\
3441.40\end{array}$ & $\begin{array}{l}0.000 \\
0.000\end{array}$ & $\begin{array}{r}-5.158913 \\
41.08156\end{array}$ & $\begin{array}{r}-5.125038 \\
41.12838\end{array}$ \\
\hline
\end{tabular}

TABLE III. MODEL OF CPT SHARE DEPENDING ON LOGARITHM OF ASSETS (IF ASSETS < RUB 0.15195 BN)

\begin{tabular}{|c|c|c|c|c|c|c|}
\hline Source & ss & $d f$ & MS & & \multirow{3}{*}{$\begin{array}{l}\text { Number of obs } \\
\text { F( 1, 1162) } \\
\text { Prob > F } \\
\text { R-squared } \\
\text { Adj R-squared } \\
\text { Root MSE }\end{array}$} & \multirow{3}{*}{$\begin{array}{lr}= & 1164 \\
= & 2447.75 \\
= & 0.0000 \\
= & 0.6781 \\
= & 0.6778 \\
= & .19106\end{array}$} \\
\hline $\begin{array}{r}\text { Mode1 } \\
\text { Residua } 1\end{array}$ & $\begin{array}{r}89.3556597 \\
42.419149\end{array}$ & $\begin{array}{rr}1 & 89 . \\
1162 & .03\end{array}$ & $\begin{array}{l}3556597 \\
6505292\end{array}$ & & & \\
\hline Total & 131.774809 & 1163 & 1330594 & & & \\
\hline ShareCPT2 & coef. & Std. Err. & $\mathrm{t}$ & $P>|t|$ & [95\% conf. & Interva1] \\
\hline $\begin{array}{r}\text { LnAssets2 } \\
\text { _cons }\end{array}$ & $\begin{array}{r}-.1585579 \\
48.06493\end{array}$ & $\begin{array}{r}.0032048 \\
.011227\end{array}$ & $\begin{array}{r}-49.47 \\
4281.18\end{array}$ & $\begin{array}{l}0.000 \\
0.000\end{array}$ & $\begin{array}{r}-.1648458 \\
48.0429\end{array}$ & $\begin{array}{r}-.15227 \\
48.08696\end{array}$ \\
\hline
\end{tabular}

Thus, if the limitation on organizing CGTs is greater than 0.15195 billion roubles, CGTs could be organized by 8,637 largest companies that would pay $41.1 \%$ of total CPT. Raising the limitation by $1 \%$ would result in 0.0514 percentage points decrease of taxes paid on average.

If the limitation includes companies with assets value less than 0.15195 billion roubles, the number of companies that could form CGT would grow significantly and account for $48.06 \%$. While raising the limitation by $1 \%$ would result in less significant decrease of taxes paid accounting for 0.0016 percentage points.

Share in CPT proceeds as the function of the revenues logarithm is displayed on Figure 3.

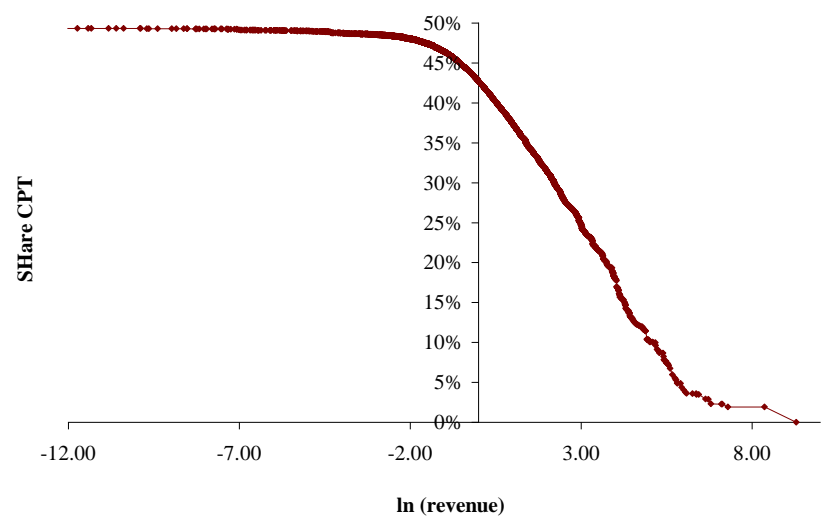

Fig. 3. Cumulative share in corporate profit tax proceeds depending on logarithm of revenues 
The relation resembles the previous one to a high degree. We generate a model representing the relation between the share in CPT proceeds and company revenues by two areas similar to the relation model of CPT share and assets value (table 4-5).

If $\operatorname{lnRevenue~} \geq-1,427$ (revenue $\geq 0,2399$ ):

$$
\text { ShareCPT }=42,1-5,47 * \text { LnRevenue }
$$

If $\operatorname{lnRevenue~}<-1,247$ (revenue $<0,2399)$ :

$$
\text { ShareCPT }=47,37-0,28 * \text { LnRevenue }
$$

where:

ShareCPT - cumulative share in corporate profit tax proceeds, [\%]

lnAssets - company revenues logarithm

TABLE IV MODEL OF CPT SHARE DEPENDING ON LOGARITHM OF REVENUE (IF REVENUE $\geq$ RUB 0.2399 BN)

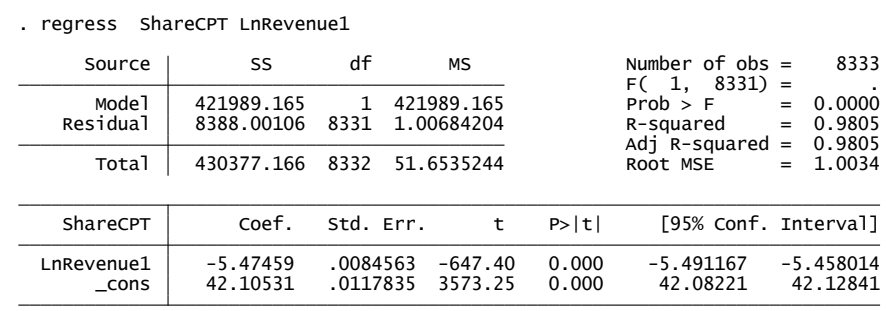

TABLE V MODEL OF CPT SHARE DEPENDING ON LOGARITHM OF

\begin{tabular}{|c|c|c|c|c|c|c|}
\hline Source & SS & $d f$ & MS & & \multirow{3}{*}{\multicolumn{2}{|c|}{$\begin{array}{lr}\text { Number of obs } & =1468 \\
\mathrm{~F}(1,1466) & =4031.84 \\
\text { Prob }>\mathrm{F} & =0.0000 \\
\text { R-squared } & =0.7333 \\
\text { Adj R-squared } & =0.7332 \\
\text { Root MSE } & =.26201\end{array}$}} \\
\hline $\begin{array}{r}\text { Mode1 } \\
\text { Residual }\end{array}$ & $\begin{array}{r}276.784187 \\
100.64022\end{array}$ & $\begin{array}{rr}1 & 276 . \\
1466 & .068\end{array}$ & $\begin{array}{l}6.784187 \\
68649536\end{array}$ & & & \\
\hline Tota1 & 377.424407 & 1467 & 57276351 & & & \\
\hline ShareCPT & coef. & Std. Err. & $\mathrm{t}$ & $P>|t|$ & {$[95 \%$ Conf. } & Interval] \\
\hline $\begin{array}{r}\text { LnRevenue } 2 \\
\text { _cons }\end{array}$ & $\begin{array}{r}-.2875778 \\
47.37032\end{array}$ & $\begin{array}{r}.004529 \\
.0135796\end{array}$ & $\begin{array}{r}-63.50 \\
3488.36\end{array}$ & $\begin{array}{l}0.000 \\
0.000\end{array}$ & $\begin{array}{r}-.2964618 \\
47.34368\end{array}$ & $\begin{array}{r}-.2786937 \\
47.39696\end{array}$ \\
\hline
\end{tabular}
REVENUE (IF REVENUE < RUB 0.2399 BN)

The relation between the share in CPT proceeds and revenues resembles - just as its models for companies with various amount of revenue do - the relation between the share in CPT proceeds and assets to a high extent.

If the limitation on company revenue is greater than 0.2399 billion roubles, CGTs would potentially pay $47.4 \%$ of CPT. Reducing the criterion value by $1 \%$ would decrease the share in CPT by 0.0029 percentage points. Such a relation remains valid until the limitation is set to less than 0.2399 billion roubles. With the specified limitation, CGTs could be formed by a maximum of 8,333 companies that would pay $42.1 \%$ of CPT. Raising the criterion value by $1 \%$ would decrease the share in CPT by 0.055 percentage points.

The models generated show similar nature of the correlation between the share in CPT and the figures of assets value and revenues. The limitations given are redundant for most companies. They make difference only for the 40 largest companies (Figure 4).

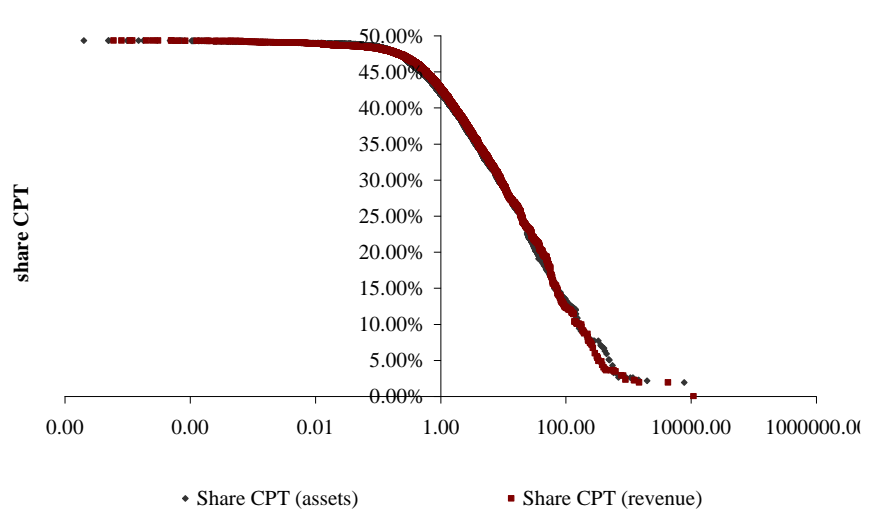

Fig. 4. Cumulative share in corporate profit tax proceeds depending on logarithm of assets and logarithm of revenues

\section{CONCLUSION}

Russia reveals the strictest and most detailed conditions for organizing CGTs in comparison with other countries studied. This is due to the goal to create the possibility of corporate profit tax consolidation for strategic companies. Loosening the restrictions in terms of assets value and revenue and their impact on the CPT share paid by CGTs is significant in case of largest taxpayers and much less tangible in case of other companies. At the same time, the relation between the share in CPT proceeds and assets value as well as revenues coincides in case of most companies. Therefore simultaneous limitations by revenues and assets value make sense only in case of the existing tight restriction on the number of companies entitled to organizing CGTs.

The parameters become redundant if the range of companies increases. The analysis of relation between the share in CPT and assets value and revenues over time might be a point interest. It could allow selecting the best criterion for lifting tight restrictions on organizing CGTs.

\section{ACKNOWLEDGEMENT}

This paper was written with the financial support from Russian Foundation for Basic Research (RFBR), scientific project No. 16-36-00184 "Mathematical modeling of the formation activities consolidated group of taxpayers to harmonize the interests of the state and taxpayers"

\section{REFERENCES}

[1] K.A.Bannova, I.N.Dolgih, A.B.Zhdanova, N.V. Pokrovskaya, "Developing The Competitive Advantage Of Companies And Regions By The Creation Of Consolidated Groups Of Taxpayers", IBIMA, 2015, pp. 834-841.

[2] N.E. Aktaev, K.A. Bannova, A.S. Balandina, I.N. Dolgih, N.V. Pokrovskaia, U.A. Rumina, A.B. Zhdanova, K.N. Akhmadeev, "Optimization Criteria For Entry Into The Consolidated Group Of Taxpayers In Order To Create An Effective Tax Mechanism And Improve The Social, Economic Development Of Regions In The Russian Federation", Procedia - Social and Behavioral Sciences, vol.166, 2015, pp. 30-35.

[3] A. V. Khaperskaya, K. A. Bannova, S. Z. Musina, "The Influence of Corporate Social Responsibility Program on the Economic Mechanism as a Whole", ICEM, 2015, pp. 390-393. 
[4] E. N. Dyrina, K. A. Bannova, "Improvement in implementation of fiscal policy of Russia”, Procedia - Social and Behavioral Sciences, vol. 166, 2015, pp.58-61.

[5] U. A. Rumina, A. S. Balandina, K. A. Bannova, "Evaluating the effectiveness of tax incentives in order to create a modern tax mechanism innovation development", Procedia - Social and Behavioral Sciences, vol. 166, 2015, pp. 156-160.

[6] I. N. Dolgih, A. B.Zhdanova, K. A. Bannova, "The influence of taxation on small enterprise development in Russia", Procedia - Social and Behavioral Sciences, vol. 166, 2015, pp.216-221

[7] K.A.Bannova, Ju.A. Ryumina, A.S. Balandina, N.V. Pokrovskaia "Consolidated taxation of corporations", Tomsk : STT, 2015, 190 p.

[8] A. Pogorletskiy, and F.Söllner, "The Russian tax system and its international competitiveness", Intereconomics, vol.43, Issue 5, 2008, pp.288-297.

[9] I. Mayburov, Y. Leontyeva, "Transport tax in Russia as a promising tool for the reduction of airborne emissions and the development of the road network", WIT Transactions on Ecology and the Environment, 2015.

[10] V. Ivanov, V. Mishchenko, and O. Maliutin, "International experience of inflation targeting: model of success for Ukraine", Actual Problems of Economics, vol. 166, № 4, 2015, pp. 414-425.

[11] JONATHAN R. KESSELMAN, "Taxpayer Behavior and the Design of a Credit Income Tax", Income-Tested Transfer Programs, 1982, pp. 215-290.

[12] GCPL consolidated net up $2 \%$ on higher tax, operating expenditure // Focus on Surfactants, vol. 2013, Issue 12, 2013, pp. 7

[13] Carmen Comaniciu , Liliana Bunescu " Taxation in Romania - Some Positive Aspects", Procedia Economics and Finance, vol. 6, 2013, pp.615-620.

[14] "Asian Paints consolidated net profit for the quarter increases by $11.8 \%$ " Focus on Powder Coatings, vol. 2015, Issue 3, 2015, pp. 2

[15] Aziz Jaafar, John Thornton, “ Tax Havens and Effective Tax Rates: An Analysis of Private versus Public European Firms", The International Journal of Accounting, vol. 50, Issue 4, 2015, pp. 435-457.

[16] "Asian Paints consolidated net sales for 2Q 2010 increases by $16.8 \%$ ", Focus on Powder Coatings, vol. 2010, Issue 2, 2010, pp. 5

[17] Don Herrmann, Tatsuo Inoue, Wayne B Thomas “ PREDICTING CONSOLIDATED EARNINGS IN JAPAN: THE INCREMENTAL USEFULNESS OF SUBSIDIARY EARNINGS", Advances in International Accounting, vol. 16, 2003, pp. 85-103

[18] Qingyue Meng, Hai Fang, PhD ${ }^{\mathrm{a}}$, Xiaoyun Liu, Beibei Yuan, Jin Xu, "Consolidating the social health insurance schemes in China: towards an equitable and efficient health system", THE LANCET, Vol. 386, Issue 10002, 2015, pp. 1484-1499.

[19] I.S. Antonova, O.A. Negodina, D.D. Vavilov, "Russian company town: creteria and diversification results", IBIMA, 2015, pp. 2181-2187

[20] N. Chistyakova, V. Spitsin, T. Gromova, N. Shabaldina, A. Dudnikova, "Comparative Investment Analysis of Industries Development in Russia and Germany". Proceedings of the 2015 International Conference on Education Reform and Modern Management, Atlantis Press; 2015; Available from: http://dx.doi.org/10.2991/ermm-15.2015.98

[21] I.E. Nikulina, A.A. Tarabanovsky "Monitoring Analysis" and "monitorcriteria" in the system of financial planning of the Autonomous Educational Institution of Higher Professional Education”, Fundamental Research, 2009, № 1, pp. 82-88.

[22] I. P. Nuzhina, O. B. Yudakhina, E. I. Kotik , E. G. Matyugina "Ecologization of Management Functions as a Factor of Sustainable Development of Construction Industry in Russia", ICEM2015, 2015, pp. 414-417 